\section{Winter Survival of St. Augustinegrass Cultivars}

\author{
Philip Busey ${ }^{1}$ \\ Fort Lauderdale Research and Education Center, University of Florida, 3205 \\ College Avenue, Fort Lauderdale, FL 33314
}

Additional index words. Stenotaphrum secundatum, freezing tolerance, cold hardiness, turfgrass

\begin{abstract}
St. Augustinegrass [Stenotaphrum secundatum (Walt.) Kuntze] has low freezing tolerance and suffers winter injury in the southeastern United States. Laboratory methods have determined that the lethal cold temperature of St. Augustinegrass stolons and buds is between $-4.5^{\circ} \mathrm{C}$ and $-7.7^{\circ} \mathrm{C}$. The field survival of $\mathrm{St}$. Augustinegrass to winter freezing is poorly known because most field reports have been based on a single location experiencing a single winter minimum air temperature. The objective of the study was to assess the winter survival of St. Augustinegrass cultivars across a range of winter minimum air temperatures occurring in experimental plantings at 24 Florida counties, following a severe Arctic cold front that moved through Florida beginning 21 Dec. 1989. Except for two counties, the limit for $\mathrm{St}$. Augustinegrass winter survival was a minimum air temperature between $-6{ }^{\circ} \mathrm{C}$ and $-9{ }^{\circ} \mathrm{C}$. Based on a nonlinear estimate using a 3-parameter sigmoidal model $\left(r^{2}=0.70, P<0.0001\right), 50 \%$ survival of St. Augustinegrass would be predicted at $-7.9^{\circ} \mathrm{C}$. Time since planting had no relationship with survival. Differences among St. Augustinegrass cultivars were observed at only two counties.
\end{abstract}

St. Augustinegrass (Stenotaphrum secundatum) is one of the most freezing-intolerant turfgrasses (DiPaola and Beard, 1992). The species is expanding rapidly as a lawn grass, especially due to human migration, in warm coastal areas (Busey, 2003). In the southeastern United States, St. Augustinegrass occurs mostly from coastal South Carolina to Florida, and across the southern coastal plain to southern Texas. For St. Augustinegrass growing in open,

Received for publication 31 Mar. 2003. Accepted for publication 1 Aug. 2003. This research was supported by the Florida Agricultural Experiment Station, and approved for publication as Journal Series No.R-09442. I thank Bonnie L. Coy and Mickey A Stanaland, who carefully propagated and shipped plant materials to all cooperators, and I thank County Extension and other cooperators at locations, Mike S. Sweat, Baker County; L. Tim Johnston, Citrus County; Ray H. Zerba, Jr., Clay County; Dan E. Schrader and Russell Skinner, Flagler County; Sydney Park-Brown, Hillsborough County; Jack J. Spears, Holmes County; H. Ed Jowers, Jackson County; Russ H. Swanson, Lake County; Jim H. Fletcher, Madison County; Geri Cashion, Manatee County; Bill Phillips, Jr., Marion County; Bob Whitty, Martin County; Gerald R. Edmondson, Sandy Lichener, and the students of Fort Walton Beach Vo-Tech Center, Okaloosa County; Eleanor Foerste, Preston Wells, and the students of St. Cloud High School, Osceola County; Clayton Hutcheson, Gene Joyner, and Alice Rosenberger, Palm Beach County; Bob Steiger, Pasco County; Joe M. Freeman, David Price, and Bok Tower Gardens, Polk County; Dan Mullins, Santa Rosa County; Jim F. Cummings, St. Lucie County; Bob Tervola and J. E. Shepherd, Suwannee County; Clay B. Olson, Taylor County; Dale L. Bennett and Fred Carlan, Wakulla County; Bruce H. Ward, Walton County; David M. Solger and Wesley King, Washington County.

${ }^{1}$ Associate Professor of Environmental Horticulture. To whom reprint requests should be addressed E-mail address: pbusey@turfgrass.com. unprotected microclimates, the northern limit of common occurrence is in U.S. Dept. of Agriculture (USDA) Plant Hardiness Zone 8b (Busey, unpublished data, 1977). Zone 8b has average annual minimum temperatures of -6.7 to $-9.4^{\circ} \mathrm{C}$ (Cathey, 1990). At the limit of its range, St. Augustinegrass exhibits winterkill in some years. Genotypic differences in winter survival are observed in the field (Wilson et al., 1977), with 'Floratam' St. Augustinegrass being completely killed, and 'Raleigh' St. Augustinegrass unaffected, following a minimum winter air temperature of $-15^{\circ} \mathrm{C}$.

Floratam has no detectable cold acclimation based on electrolyte leakage (Fry et al., 1991), and lethal cold temperatures for regrowth of stolons are -4.5 and $-6.0^{\circ} \mathrm{C}$ for Floratam and Raleigh, respectively (Maier et al., 1994). Among cultivars Floratam, Raleigh, and FX332, only Raleigh acclimates to cold. Through differential thermal analysis of excised nodes, the lethal cold temperature of St. Augustinegrass can be measured rapidly (Philley et al., 1995). Lethal temperature ranges from -4.7 to $-7.7{ }^{\circ} \mathrm{C}$ among a broad germplasm of 14 genotypes, and is highly correlated with field survival $\left(r^{2}=0.92\right)$.

Laboratory freezing tolerance evaluation has been based on simulated conditions in which the environment of detached plant parts is subjected to precise temperatures. These do not necessarily represent the full consequence of winter freezing on survival in the field, and field measurements of winter minimum air temperatures are generally taken above the ground, not near the plant. Field observations of St. Augustinegrass freezing tolerance are based on a single location experiencing a specific winter minimum air temperature. The objective of the study was to assess the winter survival of St. Augustinegrass cultivars based on a range of winter minimum air temperatures.
Plugs of St. Augustinegrasses 'FX-10,' 'FX261,' 'FX-33,' 'Floratam', and 'Seville,' were propagated and shipped to cooperators in 34 County Extension Service offices in Florida, for experimental evaluation. Plugs were $7.5 \mathrm{~cm}$ diameter, and there were 18 plugs of each of the five cultivars. Plugs were planted in three replicates in a randomized complete-block design in 21 counties, from Holmes County (lat. $30.8^{\circ} \mathrm{N}$ ) in the Florida Panhandle, to Palm Beach County (lat. $26.7^{\circ} \mathrm{N}$ ) in South Florida, between 5 Oct. 1989 and 25 Nov. 1989. Cooperators in another three counties planted only one or two replicates, because of space considerations. (In 10 remaining counties, cooperators deferred planting until warmer weather in 1990). Plot plans were separately randomized and designed to fit the dimensions available in each county location. In most cases, plots were $1.5 \mathrm{~m} \times 2.1 \mathrm{~m}$. Each cooperator was provided with blank evaluation sheets listing the characteristics to be observed and the data to be collected; cultural data to ensure maximum performance of the cultivars; maintenance/weather log sheets; a rain gauge; and a maximum-minimum thermometer, which was installed near the plots, $1.5 \mathrm{~m}$ above the ground.

A severe Arctic cold front moved into Florida on 21 Dec. 1989. Sleet, snow, or both, fell on the experimental plots, as far south as Citrus County (lat. $28.8^{\circ} \mathrm{N}$ ) in Central Florida, beginning on 22 and 23 Dec. 1989. This was followed by a hard freeze. By 24 Dec. in northern Florida, and 25 Dec. 1989 in southern Florida, record minimum temperatures were observed in many areas. The range of temperatures recorded was from $-12.8^{\circ} \mathrm{C}$ in Walton County in the Florida Panhandle (lat. $30.4^{\circ} \mathrm{N}$ ), to $-1.7^{\circ} \mathrm{C}$ in Charlotte County in southwestern Florida (lat. $26.9^{\circ} \mathrm{N}$ ). Temperatures were below $-7.0^{\circ} \mathrm{C}$ north of Tampa Bay. In Walton County, temperatures remained below freezing for $90 \mathrm{~h}$. Snow stayed on the ground at least $2 \mathrm{~d}$ as far south as Baker County (lat. $30.3^{\circ} \mathrm{N}$ ). Plots were evaluated visually by cooperators in Feb. and Mar. 1990 for winter survival, on a percent living cover basis.

Data were analyzed by analysis of variance (ANOVA) within each county location. Variances were tested by Bartlett's test (LeClerg et al., 1962), and were not homogeneous $\left(\chi^{2}=\right.$ 65.0 , df $=11, P<0.01)$, even after ignoring locations with entirely $0 \%$ survival or $100 \%$ survival. Therefore, a combined ANOVA across locations was not permitted. An estimate of average winter survival across locations was determined with nonlinear regression based on a 3-parameter sigmoidal model (Cardona et al., 1997) fitted using SigmaPlot 2001 for Windows version 7.0 (SPSS, Chicago).

\section{Results and Discussion}

The most winterkill to St. Augustinegrass cultivars was observed in counties from Marion County (lat. $29.2^{\circ} \mathrm{N}$ ) and north (Table 1). Except for Baker County and Taylor County, all locations with a minimum air temperature 
Table 1. Latitude, minimum air temperature, days after planting when minimum occurred, and survival of five cultivars of St. Augustinegrass after the winter of 1989-90, in 24 counties in Florida. Means of three replications except for Manatee (two replicates) and Hillsborough and Martin (one replicate).

\begin{tabular}{|c|c|c|c|c|c|c|c|c|}
\hline \multirow[b]{2}{*}{ County } & \multirow{2}{*}{$\begin{array}{l}\text { Latitude } \\
(\text { deg. N) }\end{array}$} & \multirow{2}{*}{$\begin{array}{c}\text { Minimum air } \\
\text { temperature }\left({ }^{\circ} \mathrm{C}\right)\end{array}$} & \multirow{2}{*}{$\begin{array}{l}\text { Days after } \\
\text { planting }\end{array}$} & \multicolumn{5}{|c|}{ St. Augustinegrass survival $(\%)^{\mathrm{z}}$} \\
\hline & & & & Floratam & $\mathrm{FX}-10$ & FX-261 & Seville & FX-33 \\
\hline Palm Beach & 26.7 & -2.2 & 87 & 100 & 100 & 100 & 100 & 100 \\
\hline Martin & 27.2 & -2.8 & --- & 80 & 100 & 100 & 100 & 100 \\
\hline Manatee & 27.5 & -3.3 & 55 & 95 & 99 & 98 & 98 & 98 \\
\hline Flagler & 29.5 & -6.1 & 40 & 63 & 65 & 90 & 95 & 97 \\
\hline Hillsborough & 28.0 & -6.7 & 9 & 35 & 70 & 20 & 50 & 90 \\
\hline Polk & 27.9 & -6.7 & 20 & 42 & 42 & 13 & 7 & 24 \\
\hline St. Lucie & 27.4 & -7.2 & 48 & 87 & 98 & 96 & 70 & 98 \\
\hline Pasco & 28.2 & -7.8 & 44 & $16 b^{z}$ & $12 \mathrm{c}$ & $17 \mathrm{~b}$ & $10 \mathrm{c}$ & $28 \mathrm{a}$ \\
\hline Osceola & 28.3 & -7.8 & 47 & 93 & 87 & 87 & 80 & 80 \\
\hline Suwannee & 30.3 & -8.9 & 54 & $70 \mathrm{a}$ & $13 \mathrm{~b}$ & $8 \mathrm{~b}$ & $7 \mathrm{~b}$ & $80 \mathrm{a}$ \\
\hline Lake & 28.8 & -8.9 & 81 & 25 & 78 & 67 & 78 & 88 \\
\hline Citrus & 28.8 & -8.9 & 101 & 63 & 83 & 83 & 68 & 62 \\
\hline Taylor & 30.1 & -9.4 & 34 & 22 & 23 & 8 & 17 & 37 \\
\hline Marion & 29.2 & -9.4 & 62 & 0 & 0 & 0 & 0 & 0 \\
\hline Madison & 30.5 & -10.0 & 59 & 0 & 0 & 0 & 0 & 0 \\
\hline Clay & 30.0 & -10.0 & 97 & 9 & 8 & 4 & 4 & 5 \\
\hline Jackson & 30.8 & -11.1 & 59 & 3 & 1 & 2 & 3 & 4 \\
\hline Wakulla & 30.2 & -11.1 & 69 & 0 & 0 & 0 & 0 & 0 \\
\hline Baker & 30.3 & -11.1 & 70 & 39 & 36 & 44 & 50 & 31 \\
\hline Okaloosa & 30.8 & -11.7 & 70 & 0 & 0 & 0 & 0 & 0 \\
\hline Holmes & 30.8 & -12.2 & 62 & 0 & 0 & 0 & 0 & 0 \\
\hline Washington & 30.8 & -12.2 & 62 & 0 & 0 & 0 & 0 & 0 \\
\hline Walton & 30.7 & -12.8 & 55 & 0 & 0 & 0 & 0 & 0 \\
\hline Santa Rosa & 30.6 & -13.3 & 62 & 0 & 0 & 0 & 0 & 0 \\
\hline Average & & & & 35 & 38 & 35 & 34 & 43 \\
\hline
\end{tabular}

${ }^{\mathrm{z}}$ Percent survival was a measure of percent living ground cover in Feb. or Mar. 1990.

${ }^{\mathrm{y}}$ Means in rows with a letter in common are not different at $P=0.05$ using the Waller-Duncan k-ratio $t$ test.

of $<-9^{\circ} \mathrm{C}$ had $<10 \%$ survival of all five St. Augustinegrass cultivars. Locations with a minimum air temperature $>-6{ }^{\circ} \mathrm{C}$ had $95 \%$ or greater survival of all cultivars. Cultivars differed in winter survival $(P<0.05)$ at only two locations, Pasco County and Suwannee County, where FX-33 had the numerically greatest survival and Seville had the lowest

survival. The five cultivars exhibited a narrow range of variation for winter survival, despite the fact that they differed in other characteristics. For example, based on another study, there was a large difference in shoot density, e.g., from 9500 tillers $/ \mathrm{m}^{2}$ for FX-261 to 3200 tillers $/ \mathrm{m}^{2}$ for Floratam (Busey, unpublished data, 1991).

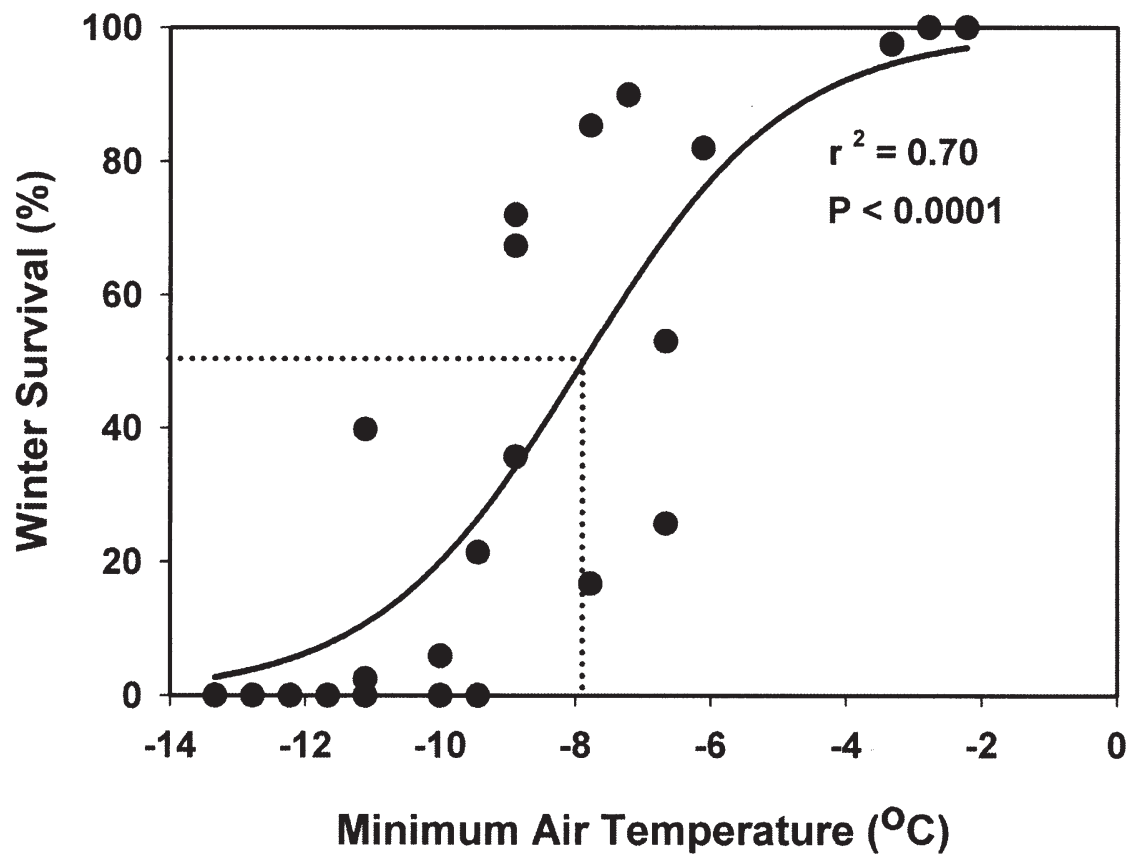

Fig. 1. Winter survival of St. Augustinegrass cultivars in 24 counties in Florida, following winter minimum air temperatures in Dec. 1989. Each value is the average of five cultivars, and most values represent three replicates. The solid line represents the nonlinear estimate of winter survival as a function of winter minimum air temperature (equation in text). The dotted line is the projection from the point of estimated $50 \%$ winter survival onto temperature.
St. Augustinegrass winter survival was estimated by the equation:

survival $(\%)=99.3 /\left\{1+\exp \left[\left(-\right.\right.\right.$ temperature $\left({ }^{\circ} \mathrm{C}\right)$ $+7.90) / 1.52]\}$

The equation explained most of the variability $\left(r^{2}=0.70\right)$ of St. Augustinegrass winter survival across locations (Fig. 1) and was very highly significant $(P<0.0001)$ overall, and each parameter was significant $(P<0.05)$. St. Augustinegrass survival of $50 \%$ was estimated at minimum winter air temperature of $-7.9^{\circ} \mathrm{C}$. Residual values (St. Augustinegrass survival observed minus predicted) were not correlated with number of days since planting.

For the cultivars in this experiment, the limit for St. Augustinegrass winter survival was a minimum air temperature between $-6^{\circ} \mathrm{C}$ and $-9{ }^{\circ} \mathrm{C}$. This was $\approx 3^{\circ} \mathrm{C}$ colder than would be estimated based on lethal temperature for regrowth of Floratam, using stolons (Maier et al., 1994), and was $\approx 3{ }^{\circ} \mathrm{C}$ colder than would be estimated based on using differential thermal analysis of excised nodes of the more cold sensitive genotypes (Philley et al., 1995). The difference between field and laboratory can be explained because in a turf canopy close to the ground, stolons and nodes should be warmer than air temperature above the ground. The limit of -6 to $-9{ }^{\circ} \mathrm{C}$ for St. Augustinegrass winter survival observed following the winter of 1989 is close to the ranges of average minimum winter air temperature, 6.7 to $-9.4^{\circ} \mathrm{C}$ for Climate Zone 8b, the most northern limit of common occurrence of St. Augustinegrass growing in open, unprotected microclimates in the southeastern United States.

\section{Literature Cited}

Busey, P. 2003. St. Augustinegrass, p. 309-330. In: M.D. Casler and R.R. Duncan (eds.). Turfgrass biology, genetics, and breeding. Wiley, Hoboken, N.J.

Cardona, C.A., R.R. Duncan, and O. Lindstrom. 1997. Low temperature tolerance assessment in Paspalum. Crop Sci. 37:1283-1291.

Cathey, H. M. 1990. USDA Plant Hardiness Zone Map. USDA Misc. Publ. No. 1475.

DiPaola, J. M. and J. B. Beard. 1992. Physiological effects of temperature stress, p. 231-267. In: D.V. Waddington, R.N. Carrow, and R.C. Shearman (eds.). Turfgrass - Agronomy Monogr. 32, Amer. Soc. of Agron., Madison, Wisc.

Fry, J.D., N.S. Lang, and R.G.P. Clifton. 1991. Freezing resistance and carbohydrate composition of 'Floratam' St. Augustinegrass. HortScience 26: 1537-1539.

LeClerg, E.L., W.H. Leonard, and A.G. Clark. 1962. Field plot technique, 2nd ed. Burgess Publishing Co., Minneapolis.

Maier, F.P., N.S. Lang, and J.D. Fry. 1994. Evaluation of an electrolyte leakage technique to predict St. Augustinegrass freezing tolerance. HortScience 29:316-318.

Philley, H.W., C.E. Watson, Jr., J.V. Krans, J.M. Goatley, Jr., and F.B. Matta. 1995. Differential thermal analysis of St. Augustinegrass. HortScience 30:1388-1389.

Wilson, C.A., J.A. Reinert, and A.E. Dudeck. 1977. Winter survival of St. Augustine grasses in north Mississippi. S. Nurserymen's Assn. Res. Conf. Ann. Rpt. 22:195-198. 